\section{DIGITAL COMMONS \\ @ UNIVERSITY OF SOUTH FLORIDA}

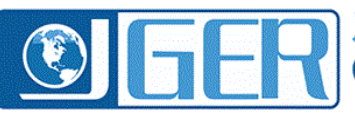

Journal of

Global Education and Research

December 2017

\title{
Wangari Maathai the educator: Straddling tradition and modernity
}

Namulundah Florence

The City University of New York, nflorence@brooklyn.cuny.edu

Follow this and additional works at: https://digitalcommons.usf.edu/jger

Part of the Education Commons

This Refereed Article is brought to you for free and open access by the M3 Center at the University of South Florida Sarasota-Manatee at Digital Commons @ University of South Florida. It has been accepted for inclusion in Journal of Global Education and Research by an authorized editor of Digital Commons @ University of South Florida. For more information, please contact digitalcommons@usf.edu.

\section{Recommended Citation}

Florence, N. (2017). Wangari Maathai the educator: Straddling tradition and modernity. Journal of Global Education and Research, 1(1), 48-67. https://www.doi.org/10.5038/2577-509X.1.1.1008

Revisions

Submission date: 05.15 .2017

1st Revision: 10.15.2017

2nd Revision: 12.08. 2017

Acceptance: 12.08.2017 


\title{
Wangari Maathai the Educator: Straddling Tradition and Modernity
}

\author{
Namulundah Florence \\ Brooklyn College \\ The City University of New York, USA \\ nflorence@brooklyn.cuny.edu
}

\begin{abstract}
Wangari Muta Mary Jo Maathai's (April 1, 1940 - September 25, 2011) public image highlights her nationality, her education both in and outside Kenya, her establishment of the Green Belt Movement (GBM) for which she received a Nobel Peace Prize in 2004, and her political activism. Advocates for female empowerment take solace in success stories like Maathai's rise from a village girl to become a global icon of leadership. Yet, her mobility was more circumstantial than it was deliberate, and is inseparable from the uneasy compromise between the traditional gender roles of her youth with the critical consciousness nurtured in advanced studies overseas. Despite the remarkable achievements of Maathai and a handful of other females, Kenyan girls still confront cultural, financial and economic hurdles in social mobility.
\end{abstract}

Keywords: Kenya, Wangari Maathai, education, cultural identity, gender roles, Green Belt Movement

\section{Introduction}

At the time of Wangari Muta Mary Jo Maathai's Nobel Prize in 2004, Green Belt Movement GBM had 6,000 tree nurseries, employed about 100,000 women and had planted 30 million trees in Kenya and other African countries (Nixon, 2006) the magnitude of which may explain why the eulogies following her death lauded her political activism, but made little mention of her professorial career; her own works fall prey to a similar omission. Maathai's 16-year university tenure as a biological scientist, when mentioned, focuses less on her academic achievements than on her social activism within the university context: the campaign for equal remuneration for women faculty with her lifetime friend and colleague Professor Vertistine Mbaya. The analysis of Maathai's atypical and yet symbolic biography draws on two primary texts: Wangari Maathai's (2006), Unbowed: A Memoir, and Namulundah Florence's (2014) Wangari Maathai: Visionary, Environmental Leader, Political Activist.

Wangari Maathai was able to achieve a large degree of educational and professional successes despite her rural beginnings in a fiercely patriarchal society and within a male dominated science discipline as well as political structure. She stands as a vanguard for all women, and particularly those struggling against seemingly insurmountable odds including personal and prevailing sociocultural barriers as well as the vestiges of colonialism in both the domestic and public sphere. Specifically, her biography illustrates the prospects and barriers of women's academic access and success in postcolonial Kenya. To this end, Maathai captures the challenges of straddling historical gender role-expectations and the prevalent cosmopolitan reality. Her appeals to a bucolic 
traditional/cultural past mirrors, although in reverse, postcolonial essentialist distinctions between the athomi (people of book), Eurocentric culture and indigenous groups. On the other hand, her work touches on but does not consistently address systemic social hierarchies that undermine women's voices and representation as well as gender-role expectations.

\section{Primary and Secondary Education}

Maathai consistently acknowledged the impact of education on her life. She recalled the excitement of her first day of school. An older cousin, Jonothan, impressed her with the power and novelty of literacy. The Ihithe Primary School run by Presbyterians, Maathai attended, comprised different ages and gender; instruction in mathematics, Kiswahili, English and Geography were in mother tongue, Kikuyu, with students only beginning to learn in English after the fourth grade. In contrast, White schools utilized English as the medium of instruction with French and Latin introduced later while and Asians initially used Guajarat, Punjabi, Hindi and Urdu (Eshiwani, 1993). While the Colony's 1949 Beecher Committee's advocated use of local languages to prepare Kenyans for available jobs many found it alienating (Anderson, 1970). Language (English and German) facility later granted Maathai access to advanced degrees overseas.

At the national level, educational access and success including per capita spending varied according to racial group: "In 1950, for example, the government allowed one British Pound per annum for the education of an African child, while the Asian had 8.3 pounds and the European had 56 Pounds spent on education per child" (Chege \& Sifuna, 2006, p. 26). European schools, disproportionately funded, trained largely the elite before increasing land shortages, high population densities and contact with whites heightened the demand for schooling among the indigenous populace. The exclusivity of liberal education opportunities during the Colonial era reinforced its perceived status among individuals and within communities (Anderson, 1970; Burgman, 1990).

Mission centers initially secluded Christian initiates to avoid their contact with ethnic traditions and to minimize the danger of "backsliding," while local communities vilified converts as collaborators. Along with opposition to missionary activity, local groups defied Church bans on female circumcision, beer drinking and polygamy as well as earlobe piercing among Maasai boys (Anderson, 1970; Tignor, 1976; Sheffield, 1973). The Kikuyu, Maathai's ethnic group and Luo spearheaded the growth of independent schools in order to meet growing demands for education and dissatisfaction with the dual system of vocational education for Blacks. In addition, there was a significant increase in British aid for economic and social development of natives following the Mau Mau revolution in the early 1950s, and indigenous groups initially focused on broadening the curriculum to include literary subjects. Book learning offered access to salaried or high-wage employment, conferring substantial benefits to families that could afford investment in a full secondary education and also reinforced class differences within communities. Education remains a "guaranteed ticket out of the perceived drudgery of subsistence farming or the cultivation of cash crops for little return” (Maathai, 2006, p. 71).

Despite substantive increases in school enrollment for Kenyan girls, few achieve Maathai's pinnacle of academic success. In 1931 out of a total population of 3,041,000 only 101,000 were enrolled in both primary and secondary education in Kenya. By 1949, of a total population of $5,406,000$, Maathai was one of 326,000 students enrolled in primary school. The estimates for 
secondary school enrollment that year were 6,000. In 1962 when Maathai was in the USA undertaking her college education, 936,000 students were enrolled in primary education with 27,000 in secondary education out of a total population of 8,636,000. By the time Maathai returned to Kenya in 1969 for her doctoral studies at the University of Nairobi, Kenya had 1,282,000 students enrolled in primary school with about 115,000 at the secondary level out of a total population of 10,943,000 (Mitchell, 1998). When Maathai was undertaking her college degree in 1963, the primary school enrollment was 891,553 compared to 5.43 million in 1994. Between 1963 and 1994, secondary school enrollments increased from 31,120 to .05 million students. At the tertiary level comprising both public and private universities enrollments increased from 452 undergraduates in one (Nairobi) University College to a student population of 40,000 between 1963 and 1994. Government expenditure in basic education creates the pyramid structure; the panacea to economic and social mobility for a few like Wangari Maathai. There has been a steady increase in student enrolments across educational levels although male students perform better on university-entrance national examinations of which female students account for only 34 percent of the top 100 students (Odhiambo, 2012), a trend heightened by poverty within "highly patriarchal traditions and cultural heritage" across the globe (Okin, 2002, p. 217).

Maathai's early access to schooling, along with the support she received from her family, were relatively unique circumstances which undoubtedly accounted for much of the achievements of her later life. At the primary, secondary and college levels, teachers recognized Maathai's talent and spurred her on. In later years, the threat of her academic achievements created friction in the domestic and public sphere. She seemed to always fall short, although she accommodated her husband's personal and professional demands: "I was also facing the challenging of venturing into what was considered a man's world. . . But Kenyan society idolizes education and considers it a panacea for all other problems. Traditionally, society puts more value on boys than on girls: Boys are provided education before girls and boys are expected to be greater achievers than girls. Therefore, it was an unspoken problem that I and not my husband had a Ph.D. and taught at the university" (Maathai, 2006, p. 139). Her venture into politics aroused the ire of the regime which urged Maathai to "seek guidance [of her place] from [her] fellow women" (Maathai, 2006, p. 196).

\section{Education Access, Success and Achievements}

The transformation of Maathai's life from village girl to professional and a global laureate is a monumental feat even in this modern age of women's progress. It was extremely rare in the 1950s and 1960s for rural Kenyans, especially girls, to attend school, and Maathai always acknowledged her privileged position in gaining formal education. Further, few Kenyans had the pro-education stance of Maathai's family at the time, reflected in the fact that, at the age of eight the oldest daughter of a family of six, she was sent to the nearby Ihithe Presbyterian Primary school near Kanungu in Nyeri district, due to her elder brother Nderitu's intervention and her mother's support. At 11, a year before the Mau Mau resurgence, Maathai joined St. Cecilia's Girls Intermediate School, run by Catholic Missionaries Sisters from Italy. The school was reputed for its good teaching and discipline. Nderitu helped pay the tuition of one shilling and fifty cents per term that many families found the excessive in the 1950's. In his eulogy, President Mwai Kibaki praised Maathai for pursuing education in an age of limited access for females and significant opposition from neighbors, teachers and friends (Chege, 2011). 
Maathai graduated top of her class from Loreto Girls Limuru in 1959, and during her studies, one of her teachers, Mother Teresia, drew her into science projects in this case, Chemistry and Biology. At the time, with few prospects, those who entered the elite class of educated women aspired primarily to nursing or teaching careers. Notwithstanding her love for science, the Catholic missionary sisters also instilled in Maathai the call to service of God and humanity, the very qualities which infused her commitment to social transformation in later years. Maathai's academic success and religious affiliation gave her access to a tertiary education in the United States.

The Kenyan airlifts started well before independence with the initiator Tom Mboya supported by the international community, looking forward to the need for educated Kenyans at independence. Local students received scholarships to attend universities in the USSR, China and the UK. In the US, a private consortium inspired by Tom Mboya of Kenya and his consortium, Harry Belafonte, Frank Montero, Sidney Poitier, Jackie Robinson, Bill Scheinman, John F. Kennedy, and Cora Weiss, educated some Africans including Maathai at American campuses. In 1959, 140 applicants competed for 81 air plane seats for a total of 451 college-level government scholarships. In 1960, three chartered planes brought 260 male students to the US, and Maathai was one of 53 female recipients of the famous series of airlifts organized by the African American Students Foundation. In total, the airlifts brought 779 students from Kenya and other East African countries to the U.S. for education (Campbell, 2011).

On the continent, relatives, friends, neighbors, local merchants and church members contributed at Harambees (self-help fundraising functions) to educate a family member. The self-help projects initiated by Kenya's first president in the 1960's continued to proliferate and develop, reached peak in the mid-1980s at 15,000-20,000 (House-Midamba, 1996). In 1952, the government created funds to support overseas studies to Britain, South Africa or the USA. Locally, the Ministry of Education covered students' fees and expenses to be repaid upon graduation. In 1995, the Ministry of Education set up a Higher Education Loans Board (HELB) that morphed and eventually expanded to offer affordable loans and scholarships to private and public college and university candidates and most recently, the service is open to all tertiary students.

Maathai saw the overseas experience as a new birth: flying over and to countries with names previously encountered only in geography lessons. In the U.S., Maathai earned her biology degree from Mount St. Scholastica College, now the Benedictine College in 1964. Maathai made the Dean's List several times despite a demanding workload but recalled the difficulty of accents. She also worked as an intern courtesy of Sr. John Marie, at St. Joseph's Hospital in Kansas City, Missouri. The Catholic Missionary Sisters at Scholastica College signed Maathai up for a sixmonth leadership course at the University of Pittsburgh, where she trained in rural development. Her paper "...was on helping women in rural areas work together and promote development efforts," a strategy she employed to initiate the Green Belt Movement." (Maathai, 2006, p. 92).

Maathai later earned a scholarship from the African-American Institute to study at the University of Pittsburgh, earning an MSc there in 1965, the first Kenyan woman to earn a master's degree. In retrospect, Pittsburgh's environmental restoration efforts following a legacy of pollution from the industrial revolution planted seeds for the Green Belt Movement which Maathai established in Kenya. Maathai admitted that the skills of embryology, microanatomy, processing tissues, and microscopy learned at Pittsburgh were pivotal to her later work in Kenya (Orlale, 2011). She 
commended her teachers at Pittsburgh University, who "'nurtured in (her) a willingness to listen, learn, to think critically and analytically, and to ask questions'- thought processes that had been damped down during her education in Kenya, but which she recognized as being central to what she would be able to achieve in life" (Shachtman, 2009, pp. 130-131) Awarding Maathai's honorary doctoral degree from the University of Pittsburgh 41 years later, Chancellor Mark A. Nordenberg took pride in the university's role in nurturing the "intellect and curiosity of a very bright young biologist," and having educated her "well and wisely," considering her achievements as the first Eastern African woman to receive a Ph.D. Following her education, jobs followed, in academic and civic positions which no black woman had filled before, and on their heels came award after award, none grander than the 2004 Nobel peace prize (Economist, 2011).

Airlift students returned home to become the nation builders of newly independent East African countries. Professor Maathai stood out among mostly male US airlift recipients who remained in academia, including Maina wa Kinyatti and Peter Muia Makau (Kenyatta University), Boniface Nyaggah (California State University), Kamuti Kiteme (City College New York, The City University of New York), Samuel Okello-Onyango (Brooklyn, the City University of New York), the Ugandan Mahmood Mamdani (Columbia University), Owino Okong'o (Great Lakes University of Kisumu), Frederick Okatcha (Kenyatta University), Geoffrey Ole Maloiy (Nairobi University), Johnston Muthiora (Nairobi University), Harrison Bwire Muyia (Wayne Community College), Gilbert Odhiambo Ogonji (Coppin State University) and John Andima (Bronx Community College, CUNY). In recent years, remittances totaling $\$ 12$ billion in 2007 from overseas trained Africans and those in the Diaspora outpace foreign direct investments (Maathai, 2010a).

In 1969, Maathai returned to Nairobi at 26, to complete her studies at the University College of Nairobi and began work as an assistant lecturer under Dr. Nderitu Mathenge, a brother-in-law to Elizabeth, a fellow graduate of Loreto-Limuru and the first African dean of the Faculty of Veterinary Medicine. In 1971, Maathai earned her PhD from Nairobi University an affiliate of the University of East Africa at Makerere in Uganda, fulfilling as she recalled, her high school ambition to attend Makerere. With the support of networks Maathai acquired overseas she secured a post in a neighboring Department of Veterinary Anatomy in 1974 and served as chair two years later. She became an associate professor in 1977 and had visions of becoming a full professor and then dean. Off-Campus, Maathai belonged to a number of civic organizations, including the Nairobi branch of the Kenya Red Cross Society, rising to become a director in 1973. Maathai was also a member of the Kenya Association of University Women. Overall, Wangari Maathai's achievements symbolize the significant role of education and the empowerment of African girls (Mungai, 2011).

Maathai received 15 degrees in addition to the honorary degree from her alma mater, the University of Pittsburgh. Eight were from the United States, one from Norway, two from Kenya (Bassey, 2014). In announcing the 2004 Nobel Peace Prize award, the Norwegian Nobel Committee commended Maathai for spearheading "ecologically viable social, economic and cultural development in Kenya and in Africa." Maathai's Noble Prize gained her and the Green Belt Movement credibility and global publicity. Her alma mater, Nairobi University established a Wangari Maathai Institute for Environmental Studies and Peace with Maathai's support. In February 2009, Maathai was appointed Distinguished Chair of the Institute. 
The Vice-President and Home Affairs Minister Kalonzo Musyoka (2011), a lawyer by training, Maathai's boss as the Minister of Environment and Natural Resources (2002-2007) recognized Maathai's significance as role model because of her comprehensive work: "She literally shattered the glass ceiling in that regard, and today, thousands of daughters, mothers and sisters are walking in her footsteps and our nation is massively better off for it." From the mud school established by Presbyterians, which was Maathai first experience of school, she graduated to a Catholic school run by Italian missionary sisters. Maathai's primary schooling was in the midst of a Mau Mau insurgency and Kenya's independence in 1963. Her Irish sisters at Loreto Limuru High School enforced an English-only policy, the impact of which never paled. Maathai's international experience provided both the language and motivation to critique Kenya's sexism, capitalism, and nationalism. Education transformed Maathai on a personal level as much as her vision for society.

On April 1, 2011, the Green Belt Movement organized a surprise party for Maathai's 71st birthday with a few family members, well-wishers and GBM associate like Benjamin Kimani a project office and Mary Wambui a business woman. Kimani likened Maathai's passion to the stature of the sturdy and tall Muthengera (Podocarpus) tree. The GBM site of the birthday party was surrounded by trees each a memory of some event; one which was planted when Maathai won the Nobel Prize. Maathai planted her last tree, the Meru oak tree at the site. Maathai's advocacy initiated a legacy of empowering women, beginning at childhood, and the international community recognized and underwrote her vision of social transformation. The seeds of hope and peace of Maathai's social activism fostered an ethos of empowerment among rural women and the general populace through teach-ins. Maathai's professorial career, her role in transforming the status of women, and subsequent Nobel Peace Prize, made her one of Africa's cultural oak trees. Her achievements and lifestyle were unique.

\section{Negotiating the Gender Divide}

Although Maathai was the first female senior lecturer, the first to hold an associate degree and to chair a department, all of which put Maathai among few Kenyan elites (Maathai, 2010a), her monumental achievements received greater coverage overseas; she was the unsung hero at home and a world icon globally. The relative lack of attention to Maathai's university career can be attributed to two factors. Her activism and scholarship focus on the Green Belt Movement and the resultant 2004 Nobel Peace, which, fell within the confines of historically sanctioned femininity (motherhood, farming, care-giving and domesticity). Maathai's scholarship centered on the GBM. Maathai (1994) herself recognized the anomaly of her achievements in a patriarchal society. On and off-Campus, Maathai confronted opposition from her spouse, colleagues and the regime. Second, her professional life as well as political career encroached on the public sphere and a primarily male discipline (science). In the Challenge for Africa, Maathai hedges her bets over tradition/modernity, (African) leadership and corruption, Christianity/cultural rituals controversies; in essence, whether or not, locals (Africans/Kenyans) failed to confront prevailing social hierarchies.

\section{Identity and Professional Career}

Maathai discovered education is not the panacea sold to children, at least females, in their hopes for a brighter future. In her 1994, Edinburgh Medal Lecture, The Bottom is Heavy Too, Maathai 
captures the burden of gender-role expectations on her aspiration and achievements. While she stood out as an intellectual and female scientist in Kenya, she also understood the weight of culture:

Anxious to be a good career woman and set a good example to fellow members of my gender, students and colleagues who had not worked with women professions before, I did what I thought mattered: I reported to work on time and was both industrious and productive. Upward mobility seemed assured if the university authority would respect what they had written in the letters of my appointment! But the inevitable happened: there was a hurdle which nobody could articulate. It was not an academic hurdle nevertheless. Mobility upwards was too slow. It was as if I did not matter as much as the others. There was something I did not have, and I could not have. The hurdle had nothing to do with passing examinations, having certificates of being a good teacher. It had everything to do with my gender! What a discovery! (Maathai, 1994, p. 8)

Maathai confronted sexism in her personal and professional life. With her arrears from the equal pay campaign she and her colleague Professor Mbaya launched against Nairobi University, Maathai bought a house and put it under her husband's name. Her lifestyle was cosmopolitan but occasionally, events compelled her to affirm her "local" roots as occurred when as her domestic roles took precedence over personal preferences and career. During her husband's political campaign, Maathai changed her dress code and took on more domestic roles to avoid jeopardizing his prospects; in her words, "It became important for me to not to wear clothing that might put me in a compromising situation because it was too tight-fitting or short. Therefore, long dresses and skirts became practical as well as comfortable and stylish. I gradually abandoned the short dresses (even my nice red one), trousers, and high heels I had accumulated and loved to wear in America when I was single and independent" (Maathai, 2006, p. 111). However, seeking a divorce in 1977, Mwangi Mathai described his wife as, "too educated, too strong, too successful, too stubborn and too hard to control" (Maathai, 2006, p. 156). Of note, she withstood a humiliating public divorce while managing to establish the Green Belt Movement. At this point, Maathai refused to play the underling or downplay her God-given talents to accommodate an insecure partner. She viewed the humiliating and publicized divorce trial as a caution to educated women who considered confronting patriarchal authority and vowed to lobby for policy to counter marital abuses. Through these experiences Maathai redefined herself and brought into question established structures of cultural gender definitions as much as she charts alternative ways to being a professional African woman.

For women, the gender ideology in communities and folktales (Florence, 2005) create a caste-like system that maintains a systematic disadvantage in social status including the "privatized, undervalued, and unpaid or underpaid" nature of their labor (Okin, 1994, p. 42). Folktales primarily depict men and male interests as central to community survival. Within schools, Fould's findings of sexist imagery in Kenyan textbooks reiterates Obura's (1991) earlier illustrations of gender bias. The imagery in Kenya's Standard Five Social Studies textbooks marginalizes women through depictions that center on males, regardless of age. A paragraph on democracy in, Unit 7: Democracy and Human Rights defines it as a "system in which all members meet and discuss their problems. . . [and yet depicts] a group of adult men and one young boy standing close together in a circle having a discussion. . The type of clothing seen in the photo varies from business suits to shorts and baseball caps. . The only woman in the picture is walking along the margins of the 
picture (Foulds, 2014, p. 666). Women's secondary status is reinforced by prevailing beliefs and practices that sanction male presence and interests. Lived experience and subliminal imagery undermine policy discourse on female empowerment.

Men like the columnist Ohaga support Kenya's Gender Bill aware of how ignorance fuels crossgender misconceptions. In his admission: "Growing up in the village, it was always a source of envy for young boys when girls who were our playmates were suddenly yanked from our midst and sent to the towns and the big city to work. In our minds, the big city, which we had only read about in books or heard about on radio, was hugely glamorous" Ohaga (2016, p. 15). The benevolent ignorance of school dropouts as a limitation in girls' education normalizes his own academic access and success. Although male students have greater options in schools and careers and are guaranteed a cultural sanction of their progress, policy makers raise alarms with any advances in girls' education. When 14 out of 47 of counties registered more boys than girls in the $2011 \mathrm{KCPE}$ national examinations results, the Minister of Education cautioned leaders, parents and communities to monitor endangered boys. A similar angst made the airwaves in 2012, when 36 out of 47 counties achieved gender parity with 18 of the 36 countries enrolling more girls. In contrast, private schools dominate the top performing category comprising 20 of the best schools at district and national levels, yet, this hardly raises national consternation.

On campus, the dominance of male students in science classrooms parallels a similar bias in textbooks, portraying females as intruders in a male world. Maathai's classes at the Department of Veterinary Anatomy were of predominantly male students, and Maathai faced skepticism, but, as she noted, the students knew who was boss at grading time. Students reluctantly acknowledged Maathai's seriousness and dedication as a professor. Maathai taught Microanatomy until 1982. Though Maathai's initial pedagogy was the familiar world of books and blackboard chalk; in later years Maathai utilized student-centered pedagogies. Former students like Dr. Gitahii Kiama, now director of the Maathai Institute appreciated Maathai's participatory pedagogical style at the Chiromo Campus. Her colleague, Mbaya recalls Maathai's passion for teaching both in and beyond the academy: "Wangari lectured many who, currently, are senior academics and administrators in most of the universities of Eastern Africa. She displayed extraordinary patience to her students... Now, I recognize that it was the same quality of patience she employed to mobilize the least informed of the civil society" (Florence, 2014, pp. 79-80).

University professors are predominantly male although the number of Kenyan female professors and Vice Chancellor/Chancellors continues to increase including about 15 prominent Kenyan women in academia like Vice Chancellors (Prof. Rosalind Mutua, Prof. Monica Mweseli, Prof Leah Marangu, Prof. Olive Mugenda and Prof. Mabel Imbuga, Mary Walingo and a Chancellors, Prof. Florida Karani and Dr. Vijoo Rattansi (Mrs). Chege and Sifuna (2006) attribute the low numbers of women administrators in Kenya to lack of political access as well as barriers to their entrance to higher education in the first place. Overall, the number of women teachers lags behind their male counterparts: "They constitute about 40 per cent of primary and 35 percent of secondary school teaching force" (p. 131).

Well before Maathai intervened to empower rural women through the Green Belt movement (GBM), she along with her longtime colleague and associate, Professor Vertistine Mbaya, lobbied for gender parity in pay and benefits such as housing, health insurance and pension for academic staff at the Nairobi University. Only single women and widows on the professional staff qualified 
for housing benefits but Maathai's attempt to unionize marginalized groups in urban areas met limited success. Against all odds, Maathai refused to back down despite pressure from colleagues as well as junior staff and professors' wives who distanced themselves from her at the behest of their husbands. A few male colleagues supported her cause. Her efforts were partially successful, at best: only she and her American colleague Professor Vertistine Mbaya received their accumulated dues, excluding the other women academics. With the funds, Maathai bought a house that later served as her refuge and the center for the GBM. Today, strikes over pay by professors has becoming a common occurrence, with the pressures of budging student enrollments and all year teaching coupled with limited budgets or corrupt officials (N. Florence, 2014).

The visibility and advocacy of women like Maathai have highlighted the predicament of marginalized girls in Kenya's male dominated society (Mungai, 2011; Ohaga, 2016; Ogutu, 2010). As during her own lifetime, Maathai's achievements would be remarkable even today, given the slow growth and progress in educating women in Kenya. Despite the obvious achievements of Mathaai and other female colleagues, women are significantly underrepresented in tertiary education, notwithstanding expansions in universities and colleges within Kenya. The proportion of girls decreases by $10 \%$ as girls ascend to the next level of education (Chege \& Sifuna, 2006). More females enroll in private universities, which offer primarily art-based programs and have a predominantly untrained teaching force, but which admit students who fail to qualify for government-funded universities. Reflecting traditional gender roles, women are still overrepresented at Kenyatta University's Home Economics Department, from which they graduate with exceptionally high grades (Mboyah, 2011).

The low numbers of females in science, technology, engineering and mathematics (STEM subjects) can be attributed to poor academic preparation, high drop-out rates, and traditional gender bias. Chege and Sifuna (2006) note how career training programs and university admission requirements favor students specialized in STEM subjects compounded by beliefs that women lack the ability to handle such subjects. Female students confront lower teacher expectations and limited access to laboratory facilities which limits access to university admissions. Although females quality for university with a point or two lower than their male counterparts, only about $30 \%$ are enrolled, and fewer still are represented at departments of science and technology or even hold professorial ranks at these institutions. They comprise about $15 \%$ in the Sciences and $4 \%$ in engineering. While the number of women scientists has increased over the years, most work in universities and not in corporations, (Mboyah, 2011) and Kenyan women dominate employment aligned with childcare-- farming, nursing and teaching, or street hawking.

\section{Political Career}

Forced out of the University of Nairobi for her political activism, Maathai reinvented herself within Kenya's civil society and later mounted a successful campaign against a sitting president's kleptocratic abuse of power. Maathai was initially surprised by the support she received during her husband's political campaign in 1969. However, while Maathai served two terms (1997 \& 2002) in the Kenyan parliament, her own campaign faced sexist as much as ethnic opposition. Despite the checkered and seemingly insignificant progress, Nzomo (2003) attributes the increase in number of elected women Members of Parliament from zero to six between independence in 1963 to 1992 and then, nine in 2002, to women's civic engagement. At Maathai's death in 2011, Kenya's Parliament of 222 members had 18 women, 10 elected and 8 nominated. Two out of 34 Ministers 
were women, with six female assistant ministers out of 46 , seven out of 34 permanent secretaries, only two out of 71 DCs are women, just 15 female ambassadors out of 45 and a mere 12 out of 44 were high court judges. (The Center for Rights Education and Awareness, 2011, p. 24) In 2016, Kenya had 47 woman representatives, 16 elected female MPs, five nominated MPs and an additional 18 women nominated to the Senate with a proposed increase of 80 more seats but this had mixed reception from men as much as women (Chege, 2016).

President Daniel arap Moi disparaged Wangari Maathai as un-African despite her role as chair of the national women's group Maendeleo Ya Wanawake (Nasong'o \& Ayot, 2007). The regime's critique of Maathai as "un-African" was erroneous given her consistent attempts to maintain links with her Gikuyu roots and value structures. In a patriarchal society, prevailing hierarchicallysanctioned cultural relations dictate much of the lives of particular members of a group. Conversely, "deviations from prescribed or culturally sanctioned norms or, in this particular case, gender roles and expectations, threaten to "undermine the unity and justice of society" (Okin, 1994, p. 30). Assertive women who defy "traditional custom pay dearly in public ridicule and indignation" (Noddings, 1989, p. 80). The regime also vilified Maathai for being too forthright, educated and uncompromising, with some labels bordering on the personal (the errant sheep and an ill-informed divorcee), when she opposed his \$200 million, 62-Uhuru Park skyscraper in 1989. The support networks Maathai developed with media and Western based activists and donors buttressed her against the public opposition from President Moi's cabinet. Though predictable, Moi's dismissal of Maathai as un-African because she transgressed gender roles and confronted a man falls prey to the flawed distinctions between the "real" African from the westernized gender roles many draw upon in associating social progress with European traditions including education, religion and more egalitarian relationships.

In former colonies, the backlash against assertive women mirrors similar repressions of locals by the white establishment. Maathai's social economic class was a double-edged sword, protecting her but also opening her up to daily disparagement. When after an arrest, a police officer yanked off her braids to humiliate her, fellow inmates shielded her and international outrage resulted in her release. The public's skepticism of elites reflects previous eras. Prior to Kenya's independence, Christian missionaries and settlers in Kenya confronted the harsh reality of educating an underclass who later threatened the racial hierarchy in their demand for "power, wealth and status," attitudes the regime viewed ungrateful, "cheeky and overconfident" (Burgman, 1990). Reflecting colonial and autocratic insecurity, Maathai's airlift compatriots were nation builders whom the regime later viewed as threats. Kenyan airlift graduates fared poorly in political campaigns. The state has a history of detaining, jailing and ostracizing Kenyan intellectuals who question the system, often deriding their positions and critiques, as too foreign, in mass media and through popular culture (Amutabi, 2007). Besides Maathai, George Saitoti, Nicholas and Beth Wambui Mugo, are among the few airlift recipients who successfully ran for political office. On the other hand, women no less than men are unnerved by the blurring of gender role-expectations.

In early October 2000, about 100 Kenyan Muslim women demonstrated against the proposed Gender Equality Bill, citing cultural imperialism. They argued that the bill undermined spiritual, cultural and customary gender roles. The columnist Njoki Chege (2016) echoes similar resistance in commending the mostly rural-based all-male opponents of the Bill which she views, "an insult to the Kenyan woman," and dismissed the proposed increase of 80 more seats at a cost of Kshs. 3.2 billion taxpayer wage bill a national disgrace. Chege rebukes female ministers whose focus on 
looks stands in sharp contrast to the likes of Wangari Maathai and Martha Karua. Maathai stood up against an entire government and its strong policemen, and had her braids yanked off her scalp but still won the Peace Prize while the Kenyan politician Martha Karua walked out on sitting President at a function. Chege ignores the cultural/structural impact on the choices of female politicians considering the benefits of alliance with the male-establishment.

In the long run, sexism was a significant hurdle for Maathai and one which both she, her supporters and proponents alluded. Countering women's limited voice and representation, feminist scholars decry the caste-like impact of patriarchal systems (Arndt, 2000; Minnich, 2005; Noddings, 1989; Okin, 1994) with female work unacknowledged and communities penalizing parties who transcend their cultural sanctioned roles of "subordination, dependency and timidity" (Mungai, 2011, p. 356). The vehemence of the backlash from patriarchal local groups arises from perceptions of women's advances as an onslaught on men's collective power in society and encroaching on the exclusive domain of men (Yuval-Davis, 1997). To this end, Michael Mungai (2011) acknowledges Maathai's symbolic role in the Kenyan structure: "In an overwhelmingly patriarchal society as my home country Kenya, it is very hard to imagine that a woman can rise to the stature of being mentioned in the same breath as humanitarian luminaries like Nelson Mandela and Archbishop Desmond Tutu. From a society that has been very adamant to invest in the education of girls, forcing the little women into marriages with men old enough to be their grandfathers, how could one of them become an icon of global leadership in a continent riddled with corrupt despots?"

\section{Incongruities in Maathai's Philosophies}

Maathai embodies and has some powerful insights for women in the (modern) cosmopolitan world although these are not articulated systematically. Her access and success to education is atypical but she fails to confront the limitations as a systemic hindrance to women. She passes the highly competitive Kenya Primary Education and the Kenya Certificate of Secondary Education but ignores the privilege of, even at the time, attending better resourced schools run by missionaries. Mother Teresia of Loreto-Limuru embraces and nurtures her interest in Chemistry and later biology at a time of dire shortages in professional teachers and science laboratories. Maathai is among Mboya's airlift students to the USA for her grades and at the request of a bishop for select Catholic school females. In the US, Maathai has a scholarship both for her undergraduate and graduate studies. Then part of an elite group, Maathai acquires a position at Nairobi University and later studies in Germany before returning to head the Department of Veterinary Anatomy although she wasn't a veterinarian. When Maathai and her colleague Professor Vertistine Mbaya campaign for equal pay, only they are paid their due. Maathai later runs for political office and with local and international networks takes on a sitting president whose proposals for development sideline the masses. The Media covers the regime's incarcerations of Maathai which help ameliorate the regime's harassment.

Maathai's is a life that would have been unimaginable for her rural-based mother or many Kenyan women. Colonization and Christianity created structures that guaranteed Maathai's socioeconomic mobility. The eulogies after her death demonstrate the anomaly of Maathai's life and achievements. Her mother lived by her father's dictates, traveling to Nakuru and from the family farm when required. Maathai (2006) even alludes to physical abuse towards her and the burden of women in polygamous marriages. She herself excused the excesses of her husband attributing it to cultural pressure: "Even if their wives had more education or more achievements, they were 
expected to demonstrate that they were in control of their households and were not henpecked by or under the control of their wives" (p. 140). Overall, Maathai is unnerved by the sexism she faces but appears to ignore its pervasive and consistent impact on women. Her transgression of genderrole expectations reflect a cultural synthesis of historic, like her mother, and more cosmopolitan gender roles in which she can navigate the public sphere to her husband and the regime's consternation.

Although Maathai's education, achievements and social activism confront sexism in private and public spheres, she fails to highlight her academic challenges and success or offer a rationale for the impact for her autonomy. Maathai falls prey to the secondary status of women in patriarchal societies, focusing on the collective rather than the individual, her family over her scholarly ambitions, registering property in her husband's name, but yet, amazed at the sexist and ethnic rhetoric in response to her achievements. Overall, she concedes in some matters (longer skirts, use of mother tongue, etc.) but asserts herself in her critique of presidential abuses of power, her husband's divorce, and at one point, leaves children with husband for an overseas assignment, etc.). In public discourse, Maathai opposes the imposition of Christianity and its denigration of African cultural traditions. Although, she credits her critical consciousness to western education and exposure, hers was a life of cultural synthesis in knowledge, beliefs and practice which creates some troubling inconsistencies in her philosophies.

\section{Patriarchy}

In the Challenge for Africa, Maathai roots the (African) reverence for elders at the expense of children, youth and women to patriarchal/seniority orally-transmitted cultural histories in contrast to education and economic progress that undermine established social hierarchies. Colonial structures sidelined and undermined traditional authority structures of older, primarily, male elders. Kenyans who collaborated with Colonial administrators had the connections and education to assume positions of leadership at independence which are now under elected officials and church leaders. However, apparently contradicting herself, Maathai lauds the Mau Mau and dismisses claims rooting people's passivity and apparent deference to leaders in African's veneration of elders, (Maathai, 2010a) implied by other Kenyan scholars (Amutabi, 2007). Yet, she attributes Africa's checkered development to the "dependency syndrome," corruption and poor governance and working as she did to shock people out of their passivity (Maathai, 2010a). The imposition of traditional values can easily slide into indoctrination despite a lack of cultural hegemony within communities. Similarly, the focus on legendary males ignores female activists in indigenous histories.

She was in a long line of women, mostly unknown and unacknowledged, few of them formally educated or acclaimed feminists, who knew they were worth more than the social definitions imposed on them. As such, her silence on fellow women's political achievements other than the empowerment of rural women through the Green Belt Movement and support of the March 1992 hunger strike by 52 mothers of prisoners raises questions. Maathai (2010a, p. 28) understood the significance of voice and representation in social transformation, alluding to Mau Mau freedom fighters when facing police security harassment. However, she credits the Mau Mau with freeing their people from the "yoke of colonization, humiliation, and exploitation," with little mention of their spouses or other female activists. Second, Maathai's memoir, Unbowed, offers few specifics

on choices that transcend gender-role expectations in the domestic sphere or professorial 
achievements in the public sphere other than the publicized confrontations with Moi's regime and her divorce.

As a Gikuyu, Maathai would know legends of female activists during the Mau Mau era (HouseMidamba, 1996; Mutiso, 1975), Mbai sya Eitu (Kamba's Clans of the Girls) from Machakos District and the Nyakenyua Mabati (acquiring corrugated iron sheets) from Maathai's birth place Nyeri District are but two historical women initiated groups. In 1913, the Giriama Mekatili Wa Menza led a rebellion against the Colonial administration's policies and in 1922, Mary Nyanjiru faced the colonists' guns when men refused to fight (Ikonya, 2008). Similarly, in African Woman in Colonial Kenya 1900-1950, Kanogo (2005) documents the predicament and agency of women like Serah and Keran, in defying traditional limitations to convert to Christianity, escape female circumcision, forced marriages and unhappy marriages as well as being ostracized by parents for going to school and their entry into a male dominant public sphere. Serah Mukabi took refuge in Thogoto mission station to get an education without her father's permission. Keran Akoto attributed her parents' reservation to education to the threat of modernity-gender equality and human rights. Some women even escaped poverty, forced or unhappy marriages and at times, sought the freedom urban centers promised (White, 1980). More recently, Rebecca Lolosoli a victim-turned activist, offers refuge to children and women fleeing forced marriages and marital abuses in Samburu, Kenya. These stories of female agency, expose the myth of established gender hierarchies and unsettle old regimes (Felski, 2011; Robin, 2011), similar in impact to the female driven solidarity of the Green Belt Movement. However, societies tend to portray these autonomous women as an aberration, unnatural, if not witches. Many women's achievements are honored only posthumously, if at all. Further, the response to women's rights advocates is mixed.

Apparently, Maathai's discourse on social change focuses on the sexism and colonial racism she experienced overlooking the intersectionality of oppression i.e., race, ethnicity, sex, class, religion, etc. There is little discourse of females denied an education, patriarchal privilege, or abusive relationships, or poverty. What one gets is the sense of resignation: "I have since learnt at the bottom of the pyramid there are very strict cultural and religious norms which govern the birth, life and death of women in society. These age-old traditions make the bottom quite heavy" (Maathai, 1994, p. 9). In contrast, in her collaboration with colleagues, activists and rural women, Maathai portrays the ambivalence towards colonization and post-colonization versus the security of tradition - membership and kinship, its rewards and penalties. Second, while Maathai's ethnic group practiced female genital mutilation (FGM) as a rite of passage for boys and girls, the issue is conspicuously absent from her scholarship. It was also a primary area of contention between missionaries and early converts prior to independence. Maathai's incongruity and conspicuous critique of sexist beliefs and practices while vilifying imperialism and Christian missionary denigration of indigenous rituals and lifestyle fails to acknowledge the history and complexity of social hierarchies.

\section{Imperialism}

Maathai acknowledged learning from everyday interactions with her mother. Through stories such as those her mother and aunt told, communities transmit tenets, triumphs, and troubles of its people across generations (Anderson, 1970). In rural areas, children engage in farm work and domestic chores alongside older relatives. Reflective of her conscious-raising efforts are two primary analogies from which Maathai consistently drew: a) the three-legged African stool; and b) the 
wrong bus syndrome (Maathai, 2010a). Using the image of the familiar traditional stool, whose seat requires the balance of its legs; Maathai inextricably linked the campaign for democratic space, sustainable natural resources and a culture of peace to a nation's development. In the "Wrong Bus Syndrome," Kenyans rely on public transportation to get around and getting on the wrong bus resonates with most audiences. However, as a biologist, Maathai drew upon her academic training as much as her primary experience in rural Kenya to forge her model of social transformation. Her professional assignment in the Department of Veterinary of Medicine at the University of Nairobi imprinted on her the role of scientists in a developing country. In the speech at the Edinburgh medal ceremony in the early 1990s, Maathai spoke of linkages among peoples, the environment and domestic animals in her research in the 1970s, which she argued, drew her to veterinary studies. The livestock industry was undergoing destruction because of a degraded environment rather than threat of indigenous stock to "the imported exotic breeds and their progenies" (Maathai, 1994, p. 8). Maathai acquired her language of critique and social transformation from her education as much as rural lifestyles.

Maathai critiques the prevailing primacy of literate over oral traditions and ways of knowing. However, while Maathai's knowledge base was primarily experiential and interactive in rural Nyeri, she later embraced western education, its abstraction and theoretical base. In later years, Maathai decried the dualism in western education and subsequent denigration of traditional cultures, peoples and languages. Five centuries later, locals define themselves using the "cracked mirror" of a Western bias rooted in a superior "power, knowledge and skills" of the colonizer (Maathai, 2010a, p. 36). The school's dismissal of students' primary cultures 'contributes to the trivialization of anything African and lays the foundation for a deeper sense of self-doubt and an inferiority complex" (Maathai, 2006, p. 60). Colonization, Maathai later argued, is dehumanizing.

Maathai (2010a) consistently decried the loss of traditional cultural structures, and yet, at the same time developed her own strategy for overcoming the limits they might have placed on her. Her cultural identity is inextricably enmeshed in the beliefs and practices of Western religions. Maathai was educated by Catholic nuns, included in the Kenyan airlift awardees at the bequest of Catholic bishops, and trained in another religious-run St. Scholastica College. The experience triggered a critical reflection on learned Christian principles and race relations although she savored early religious tenets. During her visit to her alma mater in January 2007, "With many of her classmates from her graduating class in attendance, Dr. Maathai praised the community and college for introducing her to three of the most important words she lived by: 'commitment, persistence and patience"” (Myers, 2007). Catholic sisters at her primary, secondary and college level initiated her in the sciences; in addition, the African-American Institute underwrote her studies at Pittsburgh University. She studied in Germany on scholarship. Maathai remained a practicing Christian to her death and collaborated extensively with westerners in addition to relying on foreign funds to underwrite her projects. Education undergirded her Christian identity and professional development.

Gusfield (1967) disputed the linear conception of social change that pits tradition against modernity in positing the former as "static, normatively consistent, or structurally homogenous" (p. 351), and the later as more rational, literate, Christian, progressive western-style reality. By nature, cultures exist in motion, perpetually integrating new and old structures and simultaneously exhibiting both to different degrees. Although, Kenya's displaced Kikuyu adopted Missionary lifestyles - religion, education, wage-labor, lifestyles - earlier than the culturally isolated Maasai, 
both currently exhibit a cultural synthesis that prevails across the nation with the spread of ideas and the influence of "increased transportation, communication, literacy, and horizontal mobility" (Gusfield, p. 357). Gusfield's depiction of tradition and modernity as mutually reinforcing contrasts with Maathai's critique of westernization and Christianity. She herself credits much of her knowledge and social activism to advanced learning overseas. Maathai's GBM taps into old and new concerns for its agenda, what Gusfield sees as a quest for modernity that "depends upon and often finds support in the ideological upsurge of traditionalism" (Gusfield, p. 358). She roots her concerns for the environment in her rural life and the significance of trees to human survival. Second, Maathai and her marital family spent most of their lives in cosmopolitan Nairobi rather than the village life she romanticized; it is this cultural synthesis her life achievements in education and politics reflected. Maathai overlooked, in Gusfield's words, the "mixtures and blends which reality displays" ( Gusfield, 1967, p. 362). Maathai's decries the dualism of western education and the concomitant denigration of 'traditional peoples and cultures', the assumption of positions of leadership in post-independence Kenya by various identified and unidentified individuals. Yet, her father worked for a white landowner, D.N. Neylan, who later bequeathed him 25 acres of land. Neylan also intervened when the 17-year old Maathai (2006) was arrested for not carrying her pass-book. At one point, the father took refuge in Neylan's homestead during the Mau Mau insurgency.

Contrasting tradition and culture lends to a slippery slope given ambiguities and debates of what constitutes authentic African beliefs, attitudes or practices. Regional inconsistencies in taboos and expectations only serve to magnify the fluidity of definitions and applications. Gikuyus living in rural, urban or cosmopolitan locations will have different conceptions of what is tradition as opposed to modern. Maathai worked with rural women but was never one of them. On the other hand, Maathai's professorial status complemented her role as mother and caregiver. However, Maathai appeals to the past to support her work with rural women and foster environmental sustainability, commends the Mau Mau's anti-colonial stance but fails to acknowledge the pervasive ambivalence towards education and western lifestyles as well as neo-colonial propaganda in former colonies like Kenya. Further, her GBM's focus on environmental sustainability reflects her rural experience as much as Pittsburgh's programs during Maathai's study there. As Maathai (2006, p. 11) acknowledges, "The athomi culture brought with it European ways and led to profound changes in the way Kikuyus dressed, and adorned themselves, the kinds of foods they ate, the songs they sand, and the dances they performed".

Women have diversified into lucrative even if sometimes illegal occupations to support families. Focusing on prostitution, White (1980) demonstrates women's agency in escaping limiting stereotypical gender roles and expectations in rural areas and how they re-invented themselves in urban centers. To this end, Kenya's recent gender parity policies and the creation of a Ministry of Gender, Youth, Sports, Culture and Social Services may well offer a corrective to women's under representation in national discourse and formal politics.

\section{Conclusion}

Few men had Maathai's intellectual achievements, professional expertise or global visibility as Laurent. Women's access to education and economic independence undermine prevailing gender hierarchies, and Maathai (2010a) attributed her fortitude to the grounding in her primary community, access to formal education and international exposure, what she terms her "dual 
identities" of Western and African culture. Education inducted Maathai into new activities and practices; shaping what she felt, thought and how she acted. Her vision for social transformation built on the ideas and values embraced from her interactions with family, friends, classmates and colleagues. Also present in her academic career was the same penchant towards activism, which undergirded the Green Belt Movement. The academic and social segments of her life, simply put, complemented and enhanced each other, enabling the achievements for which she is known. And while judicious in her choices and critical of the collective, Maathai's (2006) resilience sustains her against seemingly surmountable odds: "Every experience has a lesson. Each situation has a silver lining. Each person needs to raise her consciousness to a certain level so that they will not give up or succumb. If your consciousness is at such a level, you are willing to do what you think is the right thing--popular opinion notwithstanding" (p. 165).

Maathai's personal and public achievements compelled Kenyans to appreciate women in classrooms and in high places. She succeeded in establishing an identity beyond conventional gender-role expectations. In establishing the Green Belt Movement, Maathai broke with tradition, empowering rural women by drawing on what she terms "woman sense" to make of them "foresters without diplomas, a choice that did not sit well with the trained foresters, a process that undermined prevailing social hierarchies" (Maathai, 2006, P. 136). In addition, her organization of civic seminars in non-academic forums, following the disputed presidential election in 2007, pit her against her primary ethnic group and ex-President Kibaki's regime. Maathai's teach-ins raised grassroots consciousness and awakened people's yearning for democratic space and claims on natural resources.

Maathai made public policy and democratic principles palpable and understandable to the average person. Her use of familiar imagery of the three-legged African stool and the wrong bus syndrome to depict social issues makes the redress both immediate and pragmatic. Neither issue requires resources other than what is available, or the use of abstract principles of analysis to identify and resolve the problem. Replace the missing or broken stool leg and for the other analogy, get off the bus and back to the correct destination. Love for the environment is not an option it is inevitable in so far as humans are part and parcel of that environment and as Maathai reiterated, environment sustainability is inextricably linked to the quality of human life. Progress, she believed, had to be rooted in grassroots' political will to change society.

Critiques of Maathai were vitriolic when she transcended cultural gender roles in the public sphere; it was not because she was growing trees, raising a family or working alongside rural women, but the activism she engaged in. Maathai's challenge of cultural authorities-husband, employers, and regime - compelled a reassessment of taken-for-granted, social hierarchies of gender and class. On the other hand, despite Maathai's critique of Kenya's structures of privilege, she owed a large part of her success and visibility to these ethnic and professional networks of support. Maathai's reticence in fighting the sexist and ethnic loss of an initial professional appointment is striking. She attributes the job acquisition to the intervention of support networks, friends and colleagues without emphasizing her own academic credentials as the trailblazing African graduate. She later headed the department and although she decried sexism and ethnic bias, the University Chancellor and President, Jomo Kenyatta was from her ethnic group. Further, Maathai's tenure with National Council of Women of Kenya (NCWK) comprised primarily of members from her Kikuyu ethnic group although few had her level of education and none was divorced. 
Narratives of women's agency illustrate an ongoing contest of gendered ideologies in a range of forums as much as inevitable cultural transformations across Kenyan communities. As Corey (2011, p. 5) avers, when marginalized people voice their goals, however "minimal or discrete," they "raise the specter of a more fundamental change in power". In this light, Maathai's biography embodies the complexities of women's empowerment and the dilemma of adequately negotiating a viable cultural identity. The dynamism of culture illustrates how neither the past nor present worldviews are comprehensive, static or definitive. Calling for a middle ground, Minnich (2005) advocates the analysis of the past to recover and affirm women's autonomy by celebrating a more hybrid tradition. Maathai was neither the first nor the last female to transgress traditional gender role. Fueled by her education, Maathai's confrontations in domestic and public spheres helped sanction alternative gender roles and activism in campaigning for democratic effect demonstrated the fallibility of an autocratic political regime. On the other hand, self-defined women cause angst in men no less than women.

Maathai's transformative education and activism are rooted in her professorial training although she blamed Africa's demise on the industrial world's erasure of traditional knowledge. However, while African apologetics like Maathai romanticize cultures, hybrid approaches to defining and transmitting knowledge provide a more comprehensive view of the natural world and her peoples; indeed, it was her overseas experience that provided a turning point. To this end, the "western" mirror served its purpose in Maathai's life and work. Her academic access and success reflect Gusfield's thesis of cultural synthesis. Similarly, Kenyan societies ostracized early recipients of formal western education, and schools competed against informal family- and community-based education, whereby children acquired indigenous (pagan?) cultural values. Today, masses clamor for education aware of its role in social mobility. Girls were considered unsuitable for marriage and men labeled traitors and conspirators; however, they provide material and financial support to the extended family and highly educated brides command high dowries. By nature, cultural transitions are never uniform or foreseeable.

Given children's socialization and eventual acceptance of prevailing social arrangements by adulthood, as a result, they are less able to envision alternative modes of existence, influence the direction of the group (Okin, 2002). The issue is heightened for Kenyan communities in relative cultural isolation from global media barrages, and viable options or role models. In contrast, Maathai's education granted her economic independence and autonomy and by extension her founding the Green Belt Movement which served as an exit point for many rural women.

In raising the prospect of early feminists' trading political ideals for career mobility and selfinterest, Taylor, Whittier and Pelak (2009) help explain tensions in campaigns for women's rights. Differences in women's experiences and goals reflect the diversity in strategies used to resist gender inequality. The urban women who were skeptical of Maathai enjoyed privileges, some of which they owed to benevolent partners and employers. Overall, gender consciousness increases with women's access to education, and Maathai herself embraced prevailing gender roles in her youth and the early part of her married life, only later challenging the traditional roles. She worked alongside her mother on the farm and helped with household chores and childcare, and did not question her father's or brother's education access and mobility (Maathai, 2010b). Maathai lamented having played a secondary role in her marriage, albeit after the divorce. Marriage appeared to have circumscribed Maathai's lifestyle although she never expressed regret at the drastic transformation to the role of subordinate wife. Maathai consistently acknowledged the 
transformative role of education and although honoring cultural ties, avoids calling for a return to the patriarchal structures ennobling men with authority over households or confronting domestic gender roles typical of her natal family.

By contrast, Walkerdine (1990, p. 5) is skeptical about changing gender roles through education: "Individuals constituted as subjects and objects within a particular framework are reproduced by that process in relations of power." Calls for greater access to education for women overlook this quandary. On the African continent, ethnicity, religious fundamentalism, language, seniority/gerontocracy and extended family obligations define women's experience of subjugation. However, counter-narratives of women's access to education and international exposure highlight possibilities beyond traditional structures. Maathai attributes her transformation to overseas studies fostering her spirit of freedom and possibilities. The ambition infused her social activism. She cited the Scriptures to reinforce her appeals for community (Christian charity), servant leadership (Jesus Christ at the model), and responsible stewardship of the earth (Florence, 2014).

Maathai's perseverance and lack of acrimony against the status quo reflects many African women's backdoor strategies (Abwunza, 1997). Her recount of the Kikuyi folktale on Konyeki the ogre and the girls' eventual escape because of their ingenuity offers a similar imagery, which could not have escaped even Maathai's notice. As a university employee, she embraced prevailing curriculum and pedagogical structures, though her assertiveness was evident in her campaign for equal pay. Maathai became more critical of establishment, albeit not in the domestic sphere where her critique of marital arrangements was also muted until after the divorce. She focused her critique on the political machinery and the Christian missionaries' negation of African traditions, but yet attributed her motivations to overseas experiences, particularly, human rights. Maathai's support from foreign media and political support guaranteed her protection against the excesses of the Kenyan regime compared to other political activists. Seemingly, women may enjoy individual freedoms in homes but lack collective power.

Maathai's (2006) poignant tongue-in-cheek rebuttal to President Moi's vilification of her gender reflects the classical tradition of her education. A person's credibility should be based on the anatomy part that matters most, what is above their necks! If Maathai prioritizes school learning over the sexist cultural definitions and forms of knowing that Moi draws upon, she undermines a position she consistently advocates, in this case, the value of cultural rituals and beliefs as well as (indigenous?) practices. A similar incongruity surfaces in her critique of Western religion and its denigration of indigenous beliefs and practices while lauding the language of critique and empowerment in education. In a globalized system, Maathai's consistent analogy of Western knowledge and Christianity as a cracked mirror that distorts the image of Africans begs the question of credibility. In the Kenyan example, Christianity and colonial structures including western education have been inextricably linked, sharing a regional base-Europe. The critique of one system to the exclusion of the other rings hollow. In general, what passes for knowledge has for the greater part reflected Western expressions and definitions; therefore, Maathai's appeal to academic or rational knowledge conversely undermines her calls for preserving culture. If knowledge is carried in language, her use of English (I am no less guilty) endorses its centrality in what passes for knowledge and inquiry. Maathai's uneasy compromise between tradition and modernity mirrors Kenya's own problematic negotiations between national sovereignty and the dependency on foreign reserves, financial deals and military support. 


\section{References}

Abwunza, J. M. (1997). Women's voices, women's power: Dialogues of resistance from East Africa. Peterborough, Canada: Broadview Press.

Amutabi, M. N. (2007). Intellectuals and the Democratisation process in Kenya. In G. R. M. \& S. W. Nasong’o (Ed.), Kenya: The struggle for Democracy (pp. 197-226). New York, NY: Codesria/Zed Books.

Anderson, J. E. (1970). The struggle for the school: The interaction of missionary, colonial government and nationalist enterprise in the development of formal education in Kenya. London, England: Longman Group.

Arndt, S. (2000). Africa gender trouble and African Womanism: An interview with Chikwenye Ogunywemi and Wanjira Muthoni. Signs, 25(3), 709-726.

Bassey, N. (Producer). (2014, May 13). The trees will clap for her. Pambazuka. Retrieved from http://www.pambazuka.org/en/category/features/76698

Burgman, H. (1990). The way the Catholic church started in Western Kenya. Nairobi, Kenya: Mission Book Service.

Campbell, H. (Producer). (2011, Sep 29). Wangari Maathai: Reclaiming the Earth. Pambazuka. Retrieved from http://pambazuka.org/en/category/features/76724

Chege, F. N., \& Sifuna, D. N. (2006). Girls' and women's education in Kenya: Gender perspectives and trends. Nairobi, Kenya: UNESCO.

Chege, N. (2016, May 7). Yippee! That bill flopped, women don't need free seats. Daily Nation. Retrieved from https:/www.nation.co.ke/oped/blogs/That-Bill-flopped--women-don-not--need-free-seats/620-319345414 in $5 \mathrm{drz} /$ index.html

Chege, N. N. (2011, Oct 2). Maathai: Unbowed, even in death. The Standard on Sunday Newspapers, 15-17.

Economist, T. (2011. Oct 8). Wangari Maathai (Obituary). The Economist. Retrieved from http://www.economist.com/node/21531415

Eshiwani, G. S. (1993). Education in Kenya: Since independence. Nairobi, Kenya: East African Foundation Publishers.

Felski, R. (2011). Doing time: Feminist theory and postmodernist culture. Hoboken, NJ: Wiley-Blackwell.

Florence, N. (2005). From our mothers' hearths: Bukusu folktales and proverbs. Trenton, NJ: Africa World Press.

Florence, N. (2014). Wangari Maathai: Visionary, environmental leader, political activist. New York, NY: Lantern Press.

Foulds, K. (2014). Buzzwords at play: Gender, education, and political participation in Kenya. Gender and Education, 26(6), 653-671.

Gusfield, J. R. (1967). Tradition and modernity: Misplaced polarities in the study of social change. American Journal of Sociology, 72(4), 351-362.

House-Midamba, B. (1996). Gender, democratization, and associational life in Kenya. African Today, 43(3), 289305.

Ikonya, P. (Producer). (2008, May 15). Kenya is burning: Voices are missing in the making of the nation. The WIP. Retrieved from http:/www.thewip.net/contributors/2008/03/kenya_is_burning_womens_voices.html

Kanogo, T. (2005). African womanhood in colonial Kenya 1900-50. Oxford, England: James Currey.

Maathai, W. (1994). The bottom is heavy too: Even with the green belt movement. Edinburgh, Scotland: Edinburgh University Press.

Maathai, W. (2006). Unbowed: A memoir (Vol. Anchor Books): New York, NY: Alfred A. Knopf.

Maathai, W. (2010a). The challenge for Africa. New York, NY: Anchor Books.

Maathai, W. (2010b). Replenishing the Earth; Spiritual values for healing ourselves and the world. New York, NY: Doubleday.

Mboyah, D. (Producer). (2011, July 21). Realizing Kenya's dream from the sleeping sickness. Retrieved from http:/www.awcfs.org/new/index.php/women-who-make-a-difference/889-realising-kenyas-dream-fromthe-sleeping-sickness:13-14

Minnich, E. K. (2005). Transforming education (2nd ed.). Philadelphia, PE: Temple University Press.

Mitchell, B. R. (1998). International historical statistics: Africa, Asia and Oceania 1750-1993. New York, NY: Stockton Press.

Mungai, M. (Producer). (2011, September 27). Wangari Maathai and education of girls in Africa. Retrieved from http://www.huffingtonpost.com/michael-mungai/wangari-maathai-education_b_983492.html 
Musyoka, K. (2011, Oct 2). We must not lose sight of Wangari Maathai's outstanding inspiration. Sun. Retrieved from https://www.standardmedia.co.ke/article/2000043941/we-must-not-lose-sight-of-wangari-maathai-soutstanding-inspiration

Mutiso, G. C. M. (1975). Kenya: Politics, policy and society. Nairobi, Kenya: East African Literature Bureau.

Myers, J. (2007, January 29). Nobel Prize Winner's Mission Begets Hope. St. Joseph News-Press (MO). Retrieved fromhttp://www.highbeam.com/doc/1P2-14720920.html

Nasong'o, S. W., \& Ayot, T. O. (2007). Women in Kenya's politics of transition and democratisation. In G. R. a. N. o. Murunga, Shadrack W. (Ed.), Kenya: The struggle for Democracy (pp. 164-196). New York, NY: Codesria/Zed Books.

Nixon, R. (2006). Slow violence, gender, and the environmentalism of the poor. Journal of Commonwealth and Postcolonial Studies, 2(14), 14-37.

Noddings, N. (1989). Women and evil. Berkeley, CA: University of California Press.

Nzomo, M. (2003). The 2002 general elections in Kenya women's performance and prospects in parliamentary politics. A Journal Of Social \& Religious Concern, 18, 1-2.

Obura, A. P. (1991). Changing images: Portrayal of girls and women in Kenyan textbooks. Nairobi, Kenya: ACTS Press.

Odhiambo, M. (2012, Mar 25). Despite progress, gap between boys and girls still too large in education. Daily Nation. Retrieved from http://www.nation.co.ke/oped/Opinion/Gap+between+boys+and+girls+still+too+large/-/440808/1373480//view/printVersion/-/k5mclu/-/index.html

Ogutu, E. (2010). Kenya: Sanitary pads reinvented. The Standard. Retrieved from http://washafrica.wordpress.com/2008/10/08/kenya-sanitary-pads-reinvented/

Ohaga, J. B. (2016). Child Labor: Give girls a chance, send them to school. Daily Nation. Retrieved from https://www.nation.co.ke/Oped/Opinion/Give-Girls-A-Chance-And-Send-Them-To-School/4408083201018-Bi0xj2/Index.Html

Okin, M. O. (1994). Political Liberalism, justice, and gender. Ethics, 1052, 23-43.

Okin, M. O. (2002). Mistress of their own destiny: Group rights, gender, and realistic rights of exit. Ethics, 112, 205-230.

Orlale, O. (2011, April, 22 2011). The Fall of a Giant. Kenyan Woman: Advocating the Rights of Women, 22, 1.

Robin, C. (2011). The reactionary mind: Conservatism from Edmund Burke to Sarah Palin. New York, NY: Oxford University Press.

Shachtman, T. (2009). Airlift to America: How Barack Obama, Sr., John F. Kennedy, Tom Mboya, and 800 East African students changed their world and ours. New York, NY: St. Martin's Press.

Sheffield, J. R. (1973). Education in Kenya: An historical study. New York, NY: Teachers College Press.

Taylor, V., Whittier, N., \& Pelak, C. F. (2009). The women's movement: Persistence through transformation. In V. W. Taylor, Nancy and Rupp, Leila J. (Ed.), Feminist Frontiers (pp. 556-572). New York, NY: McGraw Hill,.

The Center for Rights Education and Awareness (Producer). (2011, 12 December). Status of women \& girls in Kenya: Urgent need to uphold human right. Retrieved from http://www.creawkenya.org/pdf/The_status_of_women_and_girls_in_Kenya.pdf

Tignor, R. L. (1976). The colonial transformation of Kenya: The Kamba, Kikuyu, and Maasai from 1900 to 1939. Princeton, NJ: Princeton University Press.

Walkerdine, V. (1990). Schoolgirl fictions. New York, NY: Verso.

White, L. (1980). The comforts of home: Prostitution in colonial Nairobi. Chicago, IL: The University of Chicago Press.

Yuval-Davis, N. (1997). Gender \& nation. London, England: Sage Publications. 